\title{
The next chapter in eating disorder prevention? Findings from a randomized controlled trial of a mindfulness-based intervention aimed at reducing risk for disordered eating
}

\author{
Melissa Atkinson", Tracey Wade
}

From 2013 ANZAED Conference: Inspiring Change: Person and Context

Melbourne, Australia. 23-24 August 2013

The primary objective of this study was to evaluate a mindfulness-based prevention program against an established dissonance program with regard to reducing risk for disordered eating. Adolescent girls $(\mathrm{N}=379$, Mean age $=15.70, \mathrm{SD}=0.77)$ from four high schools were randomly allocated by class to receive either a mindfulness or dissonance-based program, delivered universally, or lessons as normal (assessment-only control). Standardised measures of eating disorder behaviours and related risk factors were completed at baseline, post-program, 1-month and 6-month follow-up. Controlling for baseline, results showed significant group differences over time for weight concerns $(\mathrm{F}(6,663)=3.74, \mathrm{p}=.001)$, with both mindfulness and dissonance groups showing a greater reduction than control. No other variables demonstrated significant interactions, however main effects of time for dietary restraint, mindfulness, self-compassion, emotion dysregulation, negative affect, escape-avoidant coping, and media internalisation indicated overall improvement across groups. Improvements evident within the control group may suggest the presence of cross-contamination between classes or an impact of assessment. Further analysis is required to account for significant missing data across time points; however, these preliminary findings validate continued evaluation of mindfulness in this context.

This abstract was presented in the Prevention stream of the 2013 ANZAED Conference.

Published: 14 November 2013

\footnotetext{
* Correspondence: melissa.atkinson@flinders.edu.au
} Flinders University, Australia

( 2013 Atkinson and Wade; licensee BioMed Central Ltd. This is an Open Access article distributed under the terms of the Creative Commons Attribution License (http://creativecommons.org/licenses/by/2.0), which permits unrestricted use, distribution, and reproduction in any medium, provided the original work is properly cited.
doi:10.1186/2050-2974-1-S1-034

Cite this article as: Atkinson and Wade: The next chapter in eating disorder prevention? Findings from a randomized controlled trial of a mindfulness-based intervention aimed at reducing risk for disordered eating. Journal of Eating Disorders 2013 1(Suppl 1):O34.
Submit your next manuscript to BioMed Central and take full advantage of:

- Convenient online submission

- Thorough peer review

- No space constraints or color figure charges

- Immediate publication on acceptance

- Inclusion in PubMed, CAS, Scopus and Google Scholar

- Research which is freely available for redistribution
Ciomed Central 